\title{
EDUCATIONAL LEADERSHIP AS ACTION: TOWARDS AN OPENING OF RHYTHM
}

\author{
Y. Waghid* \\ e-mail: yw@sun.ac.za
}

\section{N. Davids*}

e-mail: nur@sun.ac.za

*Education Policy Studies

Stellenbosch University

Stellenbosch, South Africa

\section{ABSTRACT}

Nowadays, its seems as if higher education institutions have unobtrusively adopted leadership styles that seem to be in consonance with neoliberal, managerialist approaches to leadership in education. It has become apparent that, to lead, one has to occupy particular authoritative positions. Yet following such an account of leadership, institutional practices become more attuned to leadership styles in which it is erroneously assumed that people need to be told what to do and how they need to do it in order to meet the demands of the neoliberal and managerialism associated with the attainment of high levels of productivity within the institutions. Unfortunately, as we shall argue, such leadership approaches militate against the very idea of education and its intertwined practices. Consequently, we advocate a position of leadership in education that enhances the doing of action that opens up that to which Agamben (1999) refers to as 'rhythm'. Education, we argue, has a better chance of being realised and sustained if institutions attune their practices towards an opening of rhythm - one that departs from an instrumentalist, leadership-by-position towards leadership that embraces rhythmic action.

Keywords: educational leadership, managerialism, collegiality, community of thinking, rhythmic action

\section{INTRODUCTION}

For many, according to Aronowitz and Giroux (2000, 332), higher education represents a central site for keeping alive the tension between market values and those values representative of civil society that cannot be measured in narrow commercial terms but are crucial to a substantive democracy. As such, in arguing against the encroaching demands of a market-driven logic, higher education should be defended as both a public good and an autonomous sphere for the development of a critical and productive democratic citizenry (Aronowitz and Giroux 2000, 332). Traditionally, universities have been conceived as communities of practice, constituted by teaching and rigorous research engagement and debate. With support from administrative structures, 
these communities were believed to be established and cultivated through the discourses of collegiality among academics, academic leaders and students. In explaining both the reason (to be) and justification (for being), Derrida $(2004,148)$ describes the university as the 'responsibility of a community of thinking'. The notion, therefore, that the activities and cultures of universities either required managing, or were, in any meaningful sense, 'managed', says Deem $(1998,47)$, would have been regarded as heretical. Yet, as noted by Aronowitz and Giroux (2000, 333) - within the neoliberal era of deregulation - perceptions of the university as being a 'community of thinking', and of learning, have shifted to access to the job market. In response, they continue, universities and colleges are perceived, and perceive themselves, as training grounds for corporate berths.

Our central concern in this article is that it would appear that higher education institutions in South Africa have unobtrusively adopted leadership styles that seem to be in consonance with neoliberal, managerialist approaches to leadership in education. Following on this, it has erroneously been assumed that people need to be told what to do and how they need to do it in order to meet the demands of the neoliberal and managerialism associated with the attainment of high levels of productivity within the institutions. It is our contention that in the pursuit for high levels of productivity, such leadership approaches in fact militate against the very idea of education and its intertwined practices - thereby undermining the Derridian (2004) notion of 'community of thinking'. In response, we advocate a position of leadership in education that enhances the doing of action that opens up that to which Agamben (1999) refers to as 'rhythm'. To Agamben, everything is rhythm: the entire destiny of man is one heavenly rhythm, just as every work of art is one rhythm. He explains that rhythm is unbounded by structure; it is neither rational nor irrational; its essence is to flow. Such an explication, we contend, resonates with what higher education ought to embody if it is to give shape to communities of thinking. Education, we argue, has a better chance of being realised and sustained if institutions attune their practices towards an opening of rhythm - one that departs from an instrumentalist, leadership-by-position towards leadership that embraces rhythmic action.

Firstly, however, we turn our attention to the practice of managerialism, which, in our opinion, has not only become erroneously associated with leadership, but has been, and is, counter-intuitive to the purpose and responsibility of higher education.

\section{MANAGERIALISM IN HIGHER EDUCATION}

The corporatisation of higher education, according to Aronowitz and Giroux (2000, 333), has reformulated social issues as largely individual or economic considerations, cancelling out democratic impulses by either devaluing them or absorbing such impulses within the 
imperatives of the marketplace. They continue that as corporate culture and values shape university life, corporate planning replaces social planning, management becomes a substitute for leadership, and the private domain of individual achievement replaces the discourse of public politics and social responsibility. In a climate of increasing justification of expenditure and the demonstration of 'value for money', explains Deem $(1998,47)$, those who run universities are expected to ensure that such value is provided and their role as academic leaders is being subsumed by a greater concern with the overt management of sites, finance, staff, students, teaching and research. Staff in higher education, says Deem, encounter pressure both internally and externally. While internal pressure presents itself through the re-organising, controlling and regulating of academic staff and the conditions under which they work, external pressure is exerted through various higher education funding bodies, which control resource allocation and quality rankings. Those in management - such as Deans, vice-Deans, or departmental chairs - are expected to buy-in to the over-riding values implicit in both the internal and external pressures. In turn, those being managed are expected to respond with the necessary outputs in terms of research and post-graduate students so that both the internal and external pressures are adequately addressed.

Teelken (2012, 272) observes that, while managerialism might have been difficult to define initially - holding different meanings to different authors - a more nuanced conceptualisation of managerialism has taken shape. In higher education, Peters, Marshall and Fitzsimons (2000, 109) explain, managerialism has been applied to all spheres of administration, which, in turn, has led to all technical or institutional problems being homogenised as management problems. That the idea of generic understandings of managerialism or the homogenisation of management problems, would be especially contentious and disingenuous in a post-apartheid society, is abundantly evident in the largely disparate landscape that continue to define higher education in South Africa. And yet, practices of managerialism have not only taken root in higher education institutions in South Africa, but has somehow, says Luescher-Mamashela (2010, 261), legitimised the authority of university executives as professional managers. As professional managers, university executives have successfully shifted and applied leadership styles and management approaches, initially developed for business firms, to the academic context of university governance. Often uncontested, it is assumed not only that the techniques or processes necessary for better management are knowable and generally applicable, but also that they are identifiable as best practices in the private sector.

Conceived in both normative and descriptive terms, managerial orders, contends Simkins (2000, 321), represent sets of values and ideals that provide competing discourses to justify and explain particular policy and management regimes. In so doing they also embody contrasting 
assumptions about power and legitimacy. Managerialism justifies and legitimates managerial power, and requires that managers be given the 'freedom to manage', which in turn implies the delegation of power within managerial hierarchies and may also imply the disempowerment of other groups (Simkins 2000, 321). To this end, the perceived 'freedom to manage' of managers comes at the cost of the academic freedom of those not in management. Viewed from this perspective, says Simkins, managerialism provides a framework, not just for analysing the discourses that justify and legitimate change, but also for exploring the particular arrangements that are developed to translate policy agendas and goals into practical organisational consequences in particular situations. No wonder, then, that regardless of its claims of efficiency and professionalism - as highlighted by Gleeson and Shain $(1999,465)$ - the urgency of compliance implicit in managerialism has seen it shrouded in a discourse of new modes of control and allegations of ulterior motives.

To Blackmore $(2014,86)$, the changes ushered in through the neoliberal policy doxas of managerialism and marketization have seen radical changes in the field and language of higher education. Adams $(2006,9)$ explains that, within the South African context, institutional management has been elevated for the reason that it ensures the steady improvement of higher education via public accountability by way of the National Qualifications Framework (NQF) and the South African Qualifications Authority (SAQA). In this conception, he continues, management would provide this continuing improvement in quality and efficiency (financial costs) through the establishment of criteria and mechanisms for the continual assessment of higher education programmes which, in turn, is linked to funding. Another example, as noted by Harvey and Lee $(1997,1431)$, is that of the practice of institutionalised peer reviews, which, in their opinion, can be considered as part of a general trend towards managerialism. They contend that evidence of the existence of a list of core journals that are believed to count most in the ranking exercise for UK universities poses a serious threat to academic freedom and diversity within the profession. Likewise, Smeyers, De Ruyter, Waghid and Strand (2014, 647) question the dominance of publications in Web of Knowledge journals in the evaluation of educational research. In reference to the South African context, Smeyers et al. $(2014,657)$ explain that the government's funding formula for higher institutional support is biased towards accrediting articles published in Web of Knowledge journals, International Bibliography of the Social Sciences (IBSS) and selected journals on the Department of Education's (DOE) list. Articles published in these journals, they continue, are peer reviewed, accredited and subsequently subsidised - that is, the government funds institutions on the basis of their research publications, generated students enrolled and student throughputs (pass rates) per annum. 
It would appear from the above discussion that, on the one hand, managerialism, as defined by efficiency, effectiveness and excellence (Deem 1998), brings into contestation notions of academic freedom and diversity (Harvey and Lee 1997), as well as collegiality and trust. And, on the other hand, within its neoliberal agenda of deregulation, managerialism has forced the university to shift from Derrida's (2004) 'community of thinking' to a place that legitimises the authority of university executives as professional managers so as to ensure ‘value for money’ (Deem 1998) by ensuring access to the job market (Aronowitz and Giroux 2000). So, if higher education institutions have unobtrusively adopted leadership styles that seem to be in consonance with neoliberal, managerialist and authoritative approaches to leadership in education, then what type of leadership would be needed so that higher education assumes or resumes its political and social responsibility as a 'community of thinking'?

\section{LEADERSHIP IN HIGHER EDUCATION}

In exploring the styles and approaches that are associated with effective leadership in higher education, Bryman $(2007,693)$ found that, although there was substantial anecdotal reflection and also quite a lot of research on what higher education leaders need, there was surprisingly little empirical research on the topic. According to Gomes and Knowles (1999, 81, cited in Bryman, 2007, 693), '[a]lthough academic departments have been appointing heads for decades, little research exists concerning exactly how those leaders contribute to departmental culture, collaborative atmosphere, and departmental performance'. Similarly, Harris, Martin and Agnew (2004, 694) contend that, while there have been research studies that focused on leadership practices in higher education, little research has looked at the effectiveness of these practices, or at the means for increasing effectiveness, particularly at the departmental level.

A study by Juntrasook (2014), however, attempts to offer some insight into the contested constructions and meanings of leadership in higher education. Based on a study on how academics at a university in Aotearoa/New Zealand experience and understand themselves as leaders in their everyday working contexts, Juntrasook was able to identify four particular and overarching meanings of leadership - in relation to position, performance, practice and professional role model. 'Leadership as position', he explains, implies that academics are generally not leaders until they are given a leadership role within their department or institution (2014, 22). In this regard, leadership is both defined and made visible through external positioning, which is different to 'Leadership as performance', which is linked to the demonstration of competency and accomplishment in professional contexts (2014, 24). 'Leadership as practice', clarifies Juntrasook, is regarded as interactions or activities that involve others - including 
colleagues, students and team members - who, in turn, are often positioned as followers or juniors. In this context, leadership identity is claimed and enacted through the practices of academics, rather than through a formal position or their performance. The fourth meaning of leadership as 'professional role model' maintains that academics are always already leaders by virtue of their profession $(2014,27)$.

Despite its inclusive interpretation of what leadership is or could be, and despite the fact that 'leadership as practice' appeared to be the most prevalent meaning identified by the academics in the study, it was still unclear which kinds of relational practices counted as leadership, and which did not. Juntrasook explains that while the two meanings of 'position' and 'performance' underline the hierarchical nature of departmental, institutional and disciplinary community contexts in relation to individuals' leadership, the two meanings of 'practice' and 'professional role model' underline the everyday context of higher education and are less bounded (2014, 28). In suggesting a division between official and personal meanings attributed to leadership within higher education institutions, Juntrasook concludes that, in spite of institutional documents, universities never fully control how academics make sense of their leadership (2014, 25). For us, this is a significant finding in that it begins to point in the direction that perhaps leadership in higher education cannot simply be replicated through pre-defined structures. And even if these leadership and managerial structures are in place, higher education institutions are still not able to predict how these forms of leadership - if they do - might be enacted or experienced.

So, while universities might adopt managerialist-based transactional styles of leadership, it is not known for certain that these practices will lead to better results than, say, a transformational, distributed or collegial style of leadership. The only argument in support of a managerialist approach seems to be that, if it works in the private sector, it should work in the public arena of higher education.

\section{COLLEGIALITY IN HIGHER EDUCATION}

One of the main assumptions contained within a conception of managerialism - which we consider to be erroneous - is that people need to be told what to do and how they need to do it in order to attain high levels of productivity within their institutions. As discussed earlier, when heads of departments apply pressure on academics within their respective departments to teach or produce more articles, then ideas of collegiality might easily become at risk. It is highly problematic for academics within a department to feel that they are in a reciprocal relationship of professional conduct and expectation, when one of those academics has been tasked with wielding the proverbial stick of productivity. The measure of control that heads of departments seemingly have stands in 
stark contradistinction to professional autonomy or academic freedom - thereby creating tension between managerialism and collegiality, also expressed as ‘professionalism’ (Tight 2014, 1) - a practice perceived to be central to traditional conceptions of the university as a 'community of thinking'. That managerialism has been constructed as a threat to notions of collegiality implies that the desired form of leadership necessitated by higher education is indeed one of collegiality. And yet, as Tight (2014, 1-2) points out, not only does collegiality have less of a profile than managerialism in the higher education research literature - even though the idea of collegiality is of much longer standing, but ideas of collegiality might in fact not be in line with what it implies.

The low profile of collegiality can, of course, also be assigned to the way academics are appointed - with many being appointed on a contract basis (Deem, Hillyard and Reed 2007). Similarly, it is not unusual to find academics who not only have light teaching responsibilities, but equally low research output, who, in turn, place added pressure on already-productive academics to be more productive. In this instance, the tension might not necessarily be limited to being between a head of a department and academics, but between academics, where more productive academics might feel that those who are less productive should be held accountable. In other words, in the perceived absence of collegiality demonstrated by low-performing academics, a managerialist approach might be considered more desirable by those who perceive themselves to be more productive.

Seemingly, the idea of collegiality is as contentious as managerialism. In dismissing ideas about collegiality as idealistic, Dearlove (2002, 58, in Tight 2014, 2) asserts that departmental and university collegiality among academics was never as widespread as some of its proponents claim, and rarely, for example, included women or blacks. This is particularly pertinent to higher education in South Africa, where the issue of entrenched institutional discrimination continues to hamper the progress of both blacks and women in higher education (Naicker 2013). To Kligyte and Barrie (2014, 158), collegiality features in the higher education and academic leadership literature in a variety of, sometimes contradictory, ways. They explain that collegiality is cited as a component of effective leadership (Bryman 2007; Knight and Trowler 2000; Scott et al. 2008); an element of academic ethos that leaders can leverage (Bode 1999; Boice 1992; Macfarlane 2007); a vital if outmoded university governance and decision-making structure (Marginson and Considine 2000; Tapper and Palfreyman 2010); a problem to be overcome by good leadership (Fullan and Scott 2009; Ramsden 1989); as well as a defence against managerialist leadership gone astray (Nixon 2004; Rowland 2008). Kligyte and Barrie $(2014,162)$ express the opinion that the various meanings of collegiality ' $[t]$ end to be conflated in scholarly thinking and writing', leading to a disconnection between academic practices and the idealised notion of collegiality, which becomes an 'empty signifier' - something that stands 
for everything and nothing (Caesar 2007). They therefore suggest that collegiality cannot be viewed as a self-evident and unproblematic fundamental value.

Ideas of collegiality seemingly might not be extended to those who might find themselves on the periphery of traditional (biased) conceptions of a 'community of thinking'. Within a context of potential exclusion - by virtue of gender, race or sexuality - managerialism, as positioned in a dichotomous relationship to collegiality, might well be a more attractive alternative. And yet, significantly, ideas of collegiality and ideas of managerialism might not be as disconnected as one might think. Shattock (2003, 88 in Tight 2014, 4) explains that the link between collegiality and management is that ' $[\mathrm{t}]$ he main argument for a collegial style of management in universities is quite simply that it is the most effective method of achieving success in the core business' - with core business, clarifies Tight, implying that the business of universities now extends far beyond teaching and research. To this end, Chan (2001, 109, in Teelken 2012, 272) suggests that 'some dose' of managerialism in the right proportion and in the right context might be useful in universities. Similarly, Smeyers et al. $(2014,648)$ argue that it is understandable that, when large amounts of taxpayers' money are put in academia for research and teaching, a justification has to be given, as this is part of the normal functioning of a democracy.

In considering the educative value of either managerialism or collegiality as a form of leadership in higher education, it becomes clear that neither offers a clear kinship with education. On the one hand, with its emphasis on 'value for money', extrinsic measures of control and delegation of authority, managerialism certainly militates against what Peters $(1966,25)$ would consider education to be - that is, a human activity whereby an individual is initiated into 'something worthwhile'. On the other hand, ideas of collegiality might not necessarily offer the most reasonable space for equal inclusivity, and might simply be an idealistic construction of what universities are thought to symbolise (Dearlove 2002, in Tight 2014), which in fact is irreconcilable with those who might find themselves outside certain constructions of collegiality but that, like managerialism, raises questions about its educative value for higher education.

It would appear that the question of what type of leadership would be most effective in higher education can only be addressed if attention is given to what it is that is expected from higher education. In other words, what is the core focus and responsibility of higher education? Can higher education simply be understood as a commodity in the global education market, which, as Simons (2006, 33) points out, aims to serve the knowledge society through the production, transmission and dissemination of high-quality knowledge? Or is engagement in higher education simply personal fulfilment and for the intrinsic rather than the exchange value of a university degree (Biesta 2007, 468)? In other words, which practice - in terms of managerialism and collegiality - has more to offer 
education? While the economic importance of higher education cannot be disputed, its economic function cannot be at the cost of its epistemological contribution. This means that utilitarian demands cannot be allowed to submerge the role of the university as a space of scholarship, or subvert its responsibility as a 'community of thinking' in relation to societal issues, such as instability, conflict, famine or oppression. The core business of higher education, therefore, cannot be understood as singular. Instead, to conceive of the university is to conceive of its teaching, research and community engagement as being perpetually in relation to Derrida's construction of responsibility. This means that, inasmuch as the university's teaching, learning and community engagement have to be embarked upon with responsibility - that is, from within the university community itself - they also have to be in response to the community that exists beyond its walls. The 'responsibility of the community of thinking', therefore, is not confined to what thinking happens within; it also pertains to how this thinking responds to the outside. What this means, for example, is that the university cannot be impervious to an economic recession inasmuch as it cannot be insensitive to ethnic warfare.

If we accept, then, that the core business of higher education is best understood as exchanges or engagements with students, colleagues, communities, businesses and societies, then the argument can be made that the type of leadership that is required is one which, while couched in scholarship, is always in response to something or someone else. It is clear that this response might not be as responsive or receptive when couched in practices of collegiality. It is equally clear, however, that managerialism, in its instrumentalist approach of efficiency, might in fact militate against the very idea of education and its intertwined educative practices. It is for this reason, in considering more plausible forms of leadership that we conceive of leadership in higher education as perpetually being in flux between conceptions of professionalism, accountability, productivity, but also autonomy, diversity and academic freedom. As such, in the final section of this article, we argue for a position of leadership in education that enhances the doing of action that opens up what Agamben (1999) refers to as 'rhythm' that can produce more plausible forms of leadership. Education, we argue, has a better chance of being realised and sustained if institutions attune their practices towards an opening of rhythm - one that departs from an instrumentalist, leadership-by-position and instructive (performative) role towards leadership that embraces rhythmic action - that is, a leadership of doing and enacting.

\section{LEADERSHIP AS RHYTHMIC ACTION}

We have argued that managerialist forms of leadership undermine individual autonomy and collegial action to such an extent that the university finds it difficult to sustain the quest of cultivating 
'communities of thinking'. In other words, leadership is performed along the lines of performativity or a pragmatics of hard-headed calculation (Usher 2006, 286), associated with how many one can produce and gain. Such an approach to leadership reduces the work of researchers to a much maligned business dominated technological determinism (Poster, in Usher 2006, 283) - a situation that has come to be dominant at many South African universities. Such technological determinism should not be the purpose of higher education, for that would reduce higher education to a regime of 'mastery' (Edwards 2006, 277). Mastery represents a form of completion, an end to learning (and research is a form of learning), and points towards a position of finality and closure. Mastery also implies that the academic knows all there is to know, and therefore cannot learn anything more - a perception, which, in our opinion, is not only contrary to the very conception of education, but serves to undermine the responsibility of higher education. Nowadays one often witnesses the escalated promotion of some academics because their performances are deemed excellent through the practice of audit. In this sense, excellence is determined through the number of articles, book chapters, conference proceedings, and a National Research Foundation rating, regardless of whether these academics have published their work in leading academic journals or have critically engaged with the untidiness and complexity of the current higher education situation. They fail to imaginatively destabilise - or what Lyotard (1988) refers to as to paralogise - performative language games.

Now, if the purpose of higher education is not to perform mastery, how would enacting rhythmic action help us to reconfigure the purpose of leadership in higher education? In the first place, the notion of mastery does not sit easily with collegiality, because the latter always subjects the self-mastery and mastery of the subject to incredulity (that is, an inability to believe) or a loss of faith in the regimes of mastery. Rather than being a route to mastery, higher education might be better considered as a condition of ‘constant apprenticeship’ (Rikowski, in Edwards 2006, 277). If higher education can be considered as the continuous perpetuation of apprenticeships, 'communities of thinking' would evolve in which academics and students engage in meaningful work; subjects studied would generate new understandings; and learning and research would be mediated through active experimentation (Gray 2006, 320). In fact, academics would be encouraged to be reflective about why their way of thinking is desirable (or not), and these communities would be performing genuine research as opposed to mechanical action (Gray 2006, 321). This is not to say that academics do not already reflect about their thinking, but rather to draw attention to our argument that notions of mastery are irreconcilable with the educative process, and that perpetual reflection ought to be inherent in higher education. In this respect non-mastery is associated with notions of self-reflections, and openness to renewed ways of thinking and being, which ultimately gives shape to 'communities of thinking'. Through displaying such non-mastery attitudes on the part of leaders, higher education 
would be articulated as a moral activity that seeks to strengthen the moral agent within, empowering academics and students to make moral choices more intelligently on their own, which should culminate in understanding and autonomy that are expressed concretely (Gray 2006, 321). This is unlike performative managerialism, which conceives of higher education as a commodity that has to produce knowledge outputs for particular ends, often determined by the demands of university strategic targets.

However, it is the act of producing intelligent, reflective and independent research (geared towards non-mastery approaches) that seems to be drawn to actions of a rhythmic kind. In this regard, Giorgio Agamben, in his work, The man without content (1999) explains that reflective and autonomous action (that is, praxis) in the Aristotelian sense has its roots in the very condition of man [woman] as an animal - that is a living being, who is constituted by the very principle of motion that characterises life. In this sense, motion, according to Agamben (1999, 42), is to be understood as the human will in terms of desire, volition and craving - conceived by Aristotle as will, drive and vital impulse. In continuing, Agamben contends, that, ‘[f]or while poiesis [making action] constructs the space where man finds his certitude and where he ensures the freedom and duration of his action, the presupposition of work is, on the contrary, bare biological existence, the cyclical processes of the human body, whose metabolism and whose energy depend on the basic products of labor' (Agamben 1999, 43). For Agamben, the notion of work (doing) is so intimately tied to the biological cycle of humans that any attempts to argue differently have always returned to an interpretation of life, of man as a living being in which the philosophy of man's 'doing' continues to be a philosophy of life (Agamben 1999, 44). He explains that everything is rhythm: the entire destiny of man is one heavenly rhythm, just as every work of art is one rhythm. Rhythm, says Agamben, is not structure, but is instead the principle of presence that opens and maintains the work of art in its original space. Paradoxically, he explains, it is neither calculable nor rational; yet it is also not irrational. The essence of rhythm, he continues, is to flow, as in the case of water or a musical piece - which flows, and then stops. As such, says Agamben, '[w]e perceive rhythm as something that escapes the incessant flight of instants and appears almost as the presence of an atemporal dimension in time' (Agamben 1999, 45). In his analogy between music and art, Agamben states that rhythm is something that escapes an 'incessant flight of instance'. If something does not appear incessantly and instantaneously, it actually appears rhythmically; in other words, there is a moment of holding and giving back, as one might listen to and be moved by the crescendos of music. Agamben's argument is that, in the same way that we listen to music, we look at art - where we experience a suspension in time in which we reflect on the painting and re-depict the image as the painting reveals itself. In Agamben fashion, beholding a work of art is not a static action, but rather ecstatic - 'It means ecstasy in the epochal is 
the opening of rhythm which gives and holds back ...' $(1999,45)$.

Now if we consider leadership as the opening of rhythm, then momentarily one can think or hold back one's thoughts as one embarks on a practice of making meaning of what one encounters, and of the world. By implication, it can be that one at times places more emphasis on individual autonomy and less on collegiality, or vice versa, but this relationship between autonomy and collegiality is only interrupted by a rhythmic equilibrium that is never out of harmony and solidarity. It might be that the autonomy at times will be more pronounced than the collegiality, and other times the collegiality might be more accentuated than autonomy without the actions being considered dichotomous. The constructed dichotomy between autonomy and collegiality is actually nonrhythmic and therefore indefensible. For example, if the relationship between a leader and the one being led is open to rhythm, then there is already an acknowledgement that research will have both an autonomous and collegial orientation. So academics at times pursue research autonomously for its own sake, whereas at other times, and perhaps concurrently, academics engage collegially for the sake of doing research for the public good. A rhythmic approach to leadership would invariably encourage action that mutually integrates knowledge for its own sake and knowledge for socially relevant purposes.

Finally, leadership in terms of rhythmic actions will for once acknowledge research for its own sake and simultaneously acknowledge research for socially relevant purposes - thereby cultivating 'communities of thinking'. Leadership that acts rhythmically is at times in favour of knowledge being pursued for its own sake, without showing discontent towards research for socially relevant purposes, and vice versa. Similarly, leaders embarking on rhythmic action encourage autonomous individuality and simultaneously do not show an aversion to collegiality. This also implies that performative work might paradoxically be recognised momentarily without unwisely throwing the baby out with the bath water. But then, leadership should equally encourage academic work that has extended durations without being too obsessed with strategic targets for the sake of keeping the university afloat. Non-instrumental action might just begin to ensue!

\section{REFERENCES}

Biesta, G. J. J. 2010. Learning democracy in school and society: Education, lifelong learning, and the politics of citizenship. Rotterdam: Sense.

Chisholm, L. 2003. The politics of curriculum review and revision in South Africa. Paper presented at the 'Oxford' International Conference on Education and Development, 9-11 September, Oxford, United Kingdom.

Christie, P. 2006. Changing regimes: Governmentality and education policy in post-apartheid South Africa. International Journal of Educational Development 26(4): 373-381.

Adams, F. 2006. Managerialism and higher education governance: Implications for South African universities? South African Journal of Higher Education 20(1): 5-16. 
Agamben, G. 1999. The man without content. Transl. G. Albert. Stanford: Stanford University Press.

Aronowitz, S. and H. A. Giroux. 2000. The corporate university and the politics of education. The Educational Forum 64: 332-339.

Biesta, G. 2007. Towards the knowledge of democracy? Knowledge production and the civic role of the university. Studies in Philosophy and Education 26(5): 467-479.

Blackmore, J. 2014. 'Wasting talent'? Gender and the problematics of academic disenchantment and disengagement with leadership. Higher Education Research and Development 33(1): 86-99

Bryman, A. 2007. Effective leadership in higher education: A literature review. Studies in Higher Education 32(6): 693-710

Deem, R. 1998. 'New managerialism' and higher education: The management of performances and cultures in universities in the United Kingdom. International Studies in Sociology of Education 8(1): 47-70.

Deem, R., S. Hillyard and M. Reed. 2007. Knowledge, higher education and the new managerialism. Oxford: Oxford University Press.

Derrida, J. 2004. Eyes of the university: Right to philosophy 2. Transl. J. Plug. Stanford: Stanford University Press.

Edwards, R. 2006. All quiet on the postmodern front? Studies in Philosophy and Education 24(5): 273-278.

Gray, K. 2006. Spirituality, critical thinking, and the desire for what is infinite. Studies in Philosophy and Education 24(5): 315-326.

Gleeson, D. and F. Shain. 1999. Managing ambiguity: Between markets and managerialism - a case study of 'middle managers' in further education. The Sociological Review 47(3): 461-490.

Harris, J., B. N. Martin and W. Agnew. 2004. The characteristics, behaviors, and training of effective educational/leadership chairs. In The changing face(s) of educational leadership: UCEA at the crossroads, ed. D. C. Thompson and F. E. Crampton. Paper presented at the conference of the University Council for Educational Administration, 11-14 November, Kansas City, Missouri,.

Harvey, S. and F. S. Lee. 1997. Research selectivity, managerialism, and the academic labor process: The future of nonmainstream economics in U.K. universities. Human Relations 50(11): 14271460

Juntrasook, A. 2014. 'You do not have to be the boss to be a leader': Contested meanings of leadership in higher education. Higher Education Research and Development 33(1): 19-31.

Kligyte, G. and S. Barrie. 2014. Collegiality: Leading us into fantasy - the paradoxical resilience of collegiality in academic leadership. Higher Education Research and Development 33(1): 157-169,

Luescher-Mamashela, T. M. 2010. From university democratisation to managerialism: The changing legitimation of university governance and the place of students. Tertiary Education and Management 16(4): 259-283.

Lyotard, J. F. 1988. The postmodern condition. Minneapolis: University of Minnesota Press.

Naicker, L. 2013. The journey of South African women academics with a particular focus on women academics in theological education. Studia Historiae Ecclesiastica 39: 325-336.

Peters, M., J. Marshall and P. Fitzsimons. 2000. Managerialism and educational policy in a global context: Foucault, neo liberalism, and the doctrine of self management. In Ethics and education, ed. R. S. Peters (1966). London: George Allen \& Unwin Ltd.

Simkins, T. 2000. Education reform and managerialism: Comparing the experience of schools and colleges. Journal of Education Policy 15(3): 317-332.

Simons, M. 2006. Education through research at European universities: Notes on the orientation of academic research. Journal of Philosophy of Education 40(1): 31-50.

Smeyers, P., D. J. De Ruyter, Y. Waghid and Y. Strand. 2014. Publish yet perish: On the pitfalls of philosophy of education in an age of impact factors. Studies in Philosophy in Education 33: 647666. 
Teelken, C. 2012. Compliance or pragmatism: how do academics deal with managerialism in higher education? A comparative study in three countries. Studies in Higher Education 37(3): 271-290.

Tight, M. 2014. Collegiality and managerialism: A false dichotomy? Evidence from the higher education literature. Tertiary Education and Management: 1-13.

Usher, R. 2006. Lyotard’s performance. Studies in Philosophy and Education 24(5): 279-288. 